\title{
PENELITIAN TINDAKAN KELAS BERBASIS LESSON STUDY DI SD LABORATORIUM
}

\author{
Puri Selfi Cholifah ${ }^{1}$ \\ Dimyati $^{2}$ \\ Rahmah Dyah Pintasari ${ }^{3}$ \\ Herlina Mursyidah ${ }^{4}$ \\ Aflacha $^{5}$ \\ 1,2, Universitas Negeri Malang, puri.selfi.fip@um.ac.id \\ 3,4,5 SD Laboratorium Universitas Negeri Malang
}

\begin{abstract}
This study aims to photograph the implementation of classroom action research (CAR) in order to improve teacher professionalism which is implemented through lesson study. This research employed a case study qualitative research. The subjects of this study were Malang State University (UM) lecturers, 3 teachers, and 25 students of UM Laboratory Primary School. Observation, documentation and interview data were collected during the Penugasan Dosen di Sekolah (PDS) program in August-October 2018. The data analysis stage was carried out through data catagorization, interpretation and checking findings with data triangulation. The results of the research indicate that teachers have never collaborated using lesson study before. Nonetheless, a positive response appears from all the activities of implementing CAR based on lesson studies that implies there are more contribution gathered from the implementation of lesson study in improving the ability of teachers to conduct a research.
\end{abstract}

Keywords: lesson study, classroom action research, collaborative, teacher professionalism

\begin{abstract}
Abstrak: Penelitian ini bertujuan untuk untuk memotret pelaksanaan tindakan kelas sebagai upaya untuk peningkatan profesionalisme guru yang diimplementasikan melalui lesson study. Jenis penelitian yang diguankan dalam penelitian ini adalah penelitian kualitatif studi kasus. Subjek penelitian ini adalah dosen Universitas Negeri Malang (UM), 3 guru, dan 25 siswa SD Laboratorium UM. Penelitian ini menggunakan data hasil observasi, dokumentasi dan wawancara yang dikumpulkan sepanjang program Penugasan Dosen di Sekolah (PDS) pada bulan Agustus-Oktober 2018. Tahap analisis data dilakukan melalui katetgorisasi data, innterpretasi dan mengecek temuan dengan triangulasi data. Data hasil penelitian menunjukkan indikasi bahwa sebelumnya guru belum pernah berkolaborasi dengan menggunakan lesson study. Meskipun demikian respon positif tampak dari seluruh kegiatan pelaksanaan PTK berbasis lesson study bahwa tampak adanya kontribusi lebih dari pelaksanaan kolaboratif dalam meningkatkan kemampuan guru melaksanakan sebuah penelitian.
\end{abstract}

Kata kunci: lesson study, penelitian tindakan kelas, kolaboratif, profesionalisme guru 
Dalam upaya peningkatan profesionalisme guru, dibutuhkan beberapa langkah yang sinergis dengan peningkatan kompetensi guru. Salah satu langkah yang memungkinkan pengaplikasian nyata dari guru dalam peningkatan profesionalisme adalah dengan melaksanakan sebuah penelitian (Beijaard, Meijer, \& Verloop, 2004; Dewi, 2010). Penelitian yang sangat dimungkinkan untuk dilakukan seorang guru terutama guru kelas adalah dengan melaksanakan penelitian tindakan kelas (Chou, 2011). Terlebih lagi dengan pelaksanaan PTK maka akan sangat sejalan dengan pendapat ahli yang menyatakan bahwa memang diperlukan sebuah usaha untuk menyediakan struktur yang mendukung bagi peningkatan pedagogis guru (Cammarota \& Fine, 2010).

Penelitian tindakan kelas merupakan sebuah bagian dari penelitian kritis yang berfungsi untuk memberikan upaya perbakian pada pembelajaran siswa di dalam kelas (Schmuck, 2006). Penelitian ini sangat identik dengan guru karena penelitian tindakan kelas sangat sesuai dilaksanakan terutama bagi guru yang menghadapi kesulitan pembelajaran di kelasnya masing-masing. Dalam PTK sendiri, titik focuk penelitian ini bagi seorang guru adalah pada masalah atau munculnya pertanyaan terkait dengan kelasnya sendiri (Mertler, 2009; Mettetal, 2002). Secbagai contoh, apakah model pembelajaran koopertif tipe Jigsaw menjadi solusi terbaik dalam membantu siswa memahami sebuah konsep dalam pembelajaran secara berkelompok melihat permasalahan siswa di kelas terebut yang selalu bertindak individualis.

Beranjak dari definisi PTK tersebut, tidak serta merta membuat PTK bagi guru menjadi hal yang sederhana. Pelaksanaan PTK bagi guru kadang menjadi sebuah hal yang cukup menyulitkan akan tetapi wajib dan perlu untuk dilakukan sebagai salah satu upaya pelaksanaan profesionalisme guru (Blakemore, 2012). Beberapa problema yang dialamai guru dalam upaya penulisan atau pelaksanaan penelitian antara lain dungkapkan oleh beberapa studi (Arreman, 2005; Brew \& Boud, 1995; Ellis, 1997; Morrell \& Carroll, 2010). Sejalan dengan program-progam peningkatan kualitas guru, salah satu yang dapat dilakukan adalah dengan pelaksanaan lesson study sebagai sebuah upaya pelaksanaan PTK (Lewis, Perry, \& Friedkin, 2009; Somekh \& Zeichner, 2009).

Lesson study merupakan sebuah upaya yang dikenal luas dikembangkan oleh praktisi pendidikan Jepang yang berfungsi untuk mengembangkan dan mempelajari praktik mengajar guru itu sendiri (Murata, 2011). Lesson study terdiri dari beberapa tahap krusial yaitu tahap perencanaan, pelaksanaan, dan review atau dikenal dengan istilah plan, do, dan see. (Susilo, 2013; Susilo, Husnul, Ridwan, \& Jumiati, 2009). Pada tahap perencanaan, kolaborasi pendidik menjadi titik fokus untuk menentukan tingkat keberhasilan atau pencapaian siswa yang ingin dicapai. Sumbangsih ide dalam pelaksanaan perencanaan yang baik penting dilakukan termasuk di dalamanya yaitu penetapan prosedur dalam tahapan selanjutnya (Puchner \& Taylor, 2006). Pada tahap pelaksanaan, rancangan yang telah dibuat dilaksanakan dan tujuan utama pelaksanaan ini adalah untuk merekam 
keberlangsungan pembelajaran dengan focus utama adalah siswa. Pada tahapan refleksi atau see, proses pengungkapan atau refleksi terhadpa pembelajaran dilaksanakan untuk meninjau kelebihan dan kekukrangan model,. Kesemua tahapan tersebut menjadikan lesson study sebagai salah satu upaya peningkatan kualits pembelajaran yang efektif di dunia pendidikan (Murata, 2011; Susilo et al., 2009).

Di Indonesia sendiri pelaksanaan lesson study sebenarnya bukan merupakan hal yang baru. Hal ini didukung oleh beberapa studi yang sudah mengungkapkan hasil positifnya (Anggara \& Chotimah, 2012; Rozak \& Fauziah, 2013; Susilo, 2013; Winarsih \& Mulyani, 2012). Selain itu, dukungan lain didapatkan dari adanya berbagai program dari pemerintah termasuk dalam penelitian ini yaitu melalui program Penugasan Dosen di Sekolah (PDS) (Sirojjuddin, Triyoso, \& Jusmin, 2019). PDS sendiri merupakan sebuaha yapaya kolaboratif antara universitas selaku pencetak caloncalon guru dengan sekolah sebagai tempat praktisi keguruan sekolah berada. Sejalan dengan hal tersebut, kerja sama yang dapat dilakukan dalam peningkatan kualitas guru salah satunya adalah dengan pelaksanaan lesson study. Hal ini tentunya mendukung sebuah upaya dimana guru dapat mengembangkan penelitian tindakan kelas sekaligus untuk melaksanakan lesson study sebagai upaya peningkatan kulaitas pembelajaran yang dilakukan.

Dalam upaya peningkatan kualitas pembelajaran, refleksi pembelajaran perlu dilakukan agar dapat memperbaiki pembelajaran yang telah dilaksanakan. Peningkatan kualitas tersebut dapat dilakukan dengan penggabungan penelitian tindakan kelas (PTK) dan lesson study mengingat tujuan utama dari lesson study adalah mempelajari pembelajaran guru itu sendiri (Murata, 2011; Puchner \& Taylor, 2006). Adapun PTK dikaitkan dnegan lesson study karena sama-sama berfokus pada peningkatan kualitas pembelajaran (Lewis et al., 2009; Prihantoro, 2011; Subadi, 2012). Oleh sebab itu, penelitian ini mejadikan lesson study sebagai payung untuk aktivitas terkait dengan pengembangan profesional guru dengan membuka pembelajaran mereka untuk direfleksi bersama oleh guru lainnya.

Berdasarkan pelaksanaan diskusi awal dalam focus group discussion (FGD) yang dihadiri oleh dua guru kelas V dan satu guru Kelas 2 SD laboratorium bersama dengan dosen dari PGSD Universitas Negeri Malang didapatkan informasi bahwa kendala yang dihadapi guru adalah dalam pelaksanaan penelitian tindakan kelas. Alasan yang dikemukakan oleh Ibu A yaitu bahwa fokus utama yang menjadi pertimbangan bagi guru untuk menulis adalah karena mengajar. Ibu $\mathrm{R}$ juga menyatakan hal serupa dan juga menambahkan bahwa waktu untuk menulis sebuah penelitian menjadi hal yang sangat sulit untuk dialokasikan. Akan tetapi Ibu R juga ingin untuk melaksanakan sebuah PTK oleh sebab itu, Bapak D selaku dosen menyarankan untuk mengadakan penelitian tindakan kelas di Kelas Ibu R setelah Ibu R menceritakan kendalah dalam pembelajaran terutama pada muatan matematika. 
Sebelum tahap perencanaan PTK berbasis lesson study, diadakan observasi untuk menentukan bahwa memang muatan matematika menjadi pembelajaran yang harus dicarikan solusinya. Hasil observasi pada tanggal 8 Agustus 2018 oleh tiga observer menyatakan kesepakatan bahwa di kelas Ibu R menunjukkan bahwa mayoritas siswa masih belum dapat antusias terhadap pembelajaran. Hal ini terlihat dari fakta bahwa ketika guru mencoba untuk menuliskan soal matematika dengan konsep penyimpanan siswa yang aktif untuk menjawab masih didominasi oleh beberapa siswa saja. Secara umum, keterlibatan siswa dalam pembelajaran tersebut tampak hanya kurang lebih 15 (60\%) siswa yang tampak memahami pembelajaran tersebut, adapun sebanyak 10 (40\%) siswa tampak kurang antusias dalam pembelajaran. Hal yang diamati lainnya yaitu belum adanya media pembelajaran lain yang digunakan selain media gambar di buku ajar siswa.

Berakar dari permasalahan tersebut, maka penelitian tindakan kelas dengan menggunakan media pembelajaran dipilih untuk dilakukan dalam untuk menjadi sebuah solusi dari pembelajaran tersebut. Pada tahap inilah guru dan dosen yang terlibat sepakat melaksanakan PTK dalam mengatasi permasalahan tersebut. Penelitian ini menjadikan sebuah studi kasus dari pengalaman di lapangan terkait dengan program PDS antara Universitas Negeri Malang dan juga SD Laboratorium melalui pelaksanaan penelitian tindakana kelas berbasis lesson study. Tujuan dari studi kasus ini adalah untuk memotret pelaksanaan tindakan kelas sebagai upaya untuk peningkatan profesionalisme guru yang diimplementasikan melalui lesson study.

\section{METODE}

Jenis penelitian yang digunakan dalam penelitian ini adalah studi kasus sebagai sebuah metode analisis yang memungkinkan adanya deskripsi secara mendalam terkait dengan pelaksanaan lesson study. Peneliitian ini dilaksanakan di SD Laboratorium UM yang terletak di Jalan Bogor No 19 Kota Malang. Sekolah ini terletak di dekat jalan utama Veteran akan tetapi kondisinya relatif sunyi dikarenakan letak bagungan kelas yang berada di tengah kompleks area lingkungan pendidikan UM. Subyek penelitian ini adalah dosen, guru, dan siswa kelas II Bilingual SD Laboratorium tahun ajaran 2018/2019. Sebanyak 25 siswa yang terdiri dari 12 siswa perempuan dan 13 siswa laki-laki dengan karakteristik yang heterogen terlibat dalam penelitian ini di samping subjek utama yaitu 3 guru kelas di SD Laboratorium UM, dan 2 dosen PGSD Unviersitas Negeri Malang.

Penelitian ini dilaksanakan dari hasil observasi, dokumentasi, dan wawancara yang dikumpulkan sepanjang program Penugasan Dosen di Sekolah (PDS) berlangsung yaitu pada bulan Agustus, September, dan Oktober 2018. Selama kegiatan lesson study kelas yang digunakan adalah kelas II Bilingual SD Laboratorium. Sepanjang periode tersebut, peneliti mengobservasi beberapa tahapan lesson study mulai dari tahap perencanaan hingga refleksi. Setidaknya kunjungan yang 
dilakukan untuk lesson study adalah sebanyak 10 kali dengan 2 kegiatan FGD di dalamnya. Subjek dari FGD yang dilakukan yatiu 3 guru kelas di SD Laboratorium UM, dan 2 dosen PGSD. FGD dilaksanakan pada bulan Agustus, dan September 2018.

Analisis data dilakukan dengan proses pembacaan transkrip, catatan lapangan, dan dokumen lainnya dalam pelaksanaan PTK berbasis lesson study ini. Pada tahap analisis, kategorisasi data, innterpretasi, dan pengecekan hasil kategori dan interpretasi tersebut dilakukan sepajang penelitian berlangsung. Terkait dengan keabsahan temuan penelitian, cara yang dilakukan oleh peneliti yaitu dengan melakukan triangulasi data penelitian.

\section{HASIL DAN PEMBAHASAN}

Data hasil penelitian menunjukkan indikasi bahwa guru belum pernah berkolaborasi dengan cara dilakukan yaitu dengan lesson study. Pada hasil wawancara pertama setelah dilakukan FGD dinyatakan bahwa guru belum pernah melaksanakan PTK dengan kolaboratif lesson study. Meskipun demikian antusias terkait program kolaborasi dalam rangka PDS tampak dalam respon berikut. "Kalau PTK itu kita sebenarnya agak susah, tapi tidak apa bu, saya semangat pokoknya saya ingin bisa belajar hal baru." (Ibu A, 8 Agustus 2018).

Terlebih lagi, respon Ibu R yang menyatakan kesediaannya untuk menjadi guru model dalam kegiatan lesson study menjadi sebuah titik positif. Hal tersebut menunjukkan adanya indikasi dari minat guru terhadap pengembangan diri yang lebih tinggi. Hal itu tampak pada respon wawancara berikut "Ya.. pelaksanaannya di kelas saya saja, soalnya ini saya menemukan masalah, anak-anak sulit sekali memahami muatan matematika yang penjumlahan dan pengurangan. Masih banyak yang bingung. Untuk PTK program PDS ini bisa dilakukan di kelas saya saja" (Ibu R, 8 Agustus 2018).

Selanjutnya yang dilakukan oleh tim PDS adalah melaksanakan tahap perencanaan (plan) pada tanggal 13 Agustus 2018. Pada tahap ini, Ibu R selaku wali kelas II Billingual menggagas rencana untuk mengembangkan RPP yang kemudian dibantu oleh Dosen D. Pada faktanya, siswa memang kesulitan untuk mengembangkan lebih jauh tentang materi penjumlahan dan penguruangan dengan menyimpan pada muatan matematika. Ibu R menyajikan data bahwa 60 persen siswa dari siswa kelas 2 Billingual masih belum mampu menyelesaikan permasalahan matematika dengan konsep menyimpan. Data hasil latihan soal matematika menunjukkan bahwa sebanyak 15 siswa masih belum melebihi KKM, dan hanya 10 siswa saja yang sudah dapat menunjukkan ketercapaian KKM (Dokumentasi pretest tanggal 10 Agustus 2018).

Selama tahap plan berlangsung terjadi diskusi bahwa media menjadi salah satu upaya yang dapat dilakukan dalam peningkatan pemahaman konsep matematika siswa kelas II Billingual. Berdasarkan tinjauan fakta-fakta tersebut, didapatkan permasalahan utama yang menjadi akar dari 
belum tuntasnya pembelajaran muatan inti matematika dikarenakan belum tersedianya media yang sesuai. Penggunaan media pembelajaran matematika merupakan salah satu komponen esensial mengingat matematika merupakan konsep abstrak (Phonguttha, Tayraukham, \& Nuangchalerm, 2009; Widodo, 2018). Terlebih lagi, hasil penelitian menunjukkan bahwa pembelajaran matematika secara umum tidak dinikmati oleh siswa meskipun mereka mengetahui bahwa matematika merupakan subjek yang penting (Forgasz \& Markovits, 2018; Markovits \& Forgasz, 2017). Oleh sebab itu penting untuk mengoptimalisasi pembelajaran yang berlangsung di dalam kelas.

Salah satu faktor utama yang mempengaruhi kesuksesan pembelajaran matematika yaitu dengan penggunaan media pembelajaran (Widodo, 2018). Salah satu contoh yang dapat dilakukan untuk siswa yang kesulitan belajar matematika yaitu dengan pengoptimalisasian penggunaan media scaffolding (Sutiarso \& Coesamin, 2018). Studi lain menunjukkan bahwa siswa yang belajar dalam konteks yang nyata dengan penggunaan media dapat meningkatkan hasil belajar siswa dalam pembelajaran matematika (Laurens, Batlolona, Batlolona, \& Leasa, 2018; Mulbar \& Zaki, 2018; Sidabutar, 2016). Berdasarkan hasil studi tersebut dapat disimpulkan bahwa penggunaan media dalam pembelajaran matematika menjadi sebuah hal yang fundamental dalam membantu pemahaman siswa terutama pada konsep yang abstrak.

Pemilihan media pembelajaran menjadi sangat fundamental bagi seorang guru, terlebih lagi bila dikaitkan dengan media yang harus sesuai dengan materi, sesuai karakteristik siswa, dan sesuai dengan karakteristik lingkungan. Secara psikologi, siswa usia kelas II SD masih berada dalam tahap operasional konkrit sehingga studi-studi menunjukkan aplikasi pemahaman konsep di kelas bawah SD dikaitkan dengan penggunaan matematika yang realistik (Fitriani \& Maulana, 2016; Yeni, 2011). Berkaitan dengan hal tersebut, penggunaan media abstrak berupa gambar saja untuk anak usia awal dirasa masih belum mampu memberikan pemahaman terkait konsep matematika yang abstrak. Pentingnya penggunaan benda-benda di sekitar yang diwadahi dalam skema kontekstual mempermudah siswa dalam mengaitkan situasi dunia nyata dengan permasalahan matematika (Muhsetyo, Krisnadi, \& Wahyuningrum, 2014).

Berdasarkan uraian di atas diperlukan sebuah solusi dari permasalahan yang ada yaitu dengan diberikan media realistik dari lingkungan anak yang dinamai dengan Multi Smart Stick. Gagasan ini muncul dari Dosen D yang mengamati bahwa anak SD cenderung lebih mudah memahami materi dengan konsep yang realistik. Penamaan media itu sendiri dimunculkan karena penggunaan media dari bambu tersebut memiliki beberapa keunggulan yang sangat fleksibel dan juga aman digunakan oleh siswa. Hal tersebut tampak pada respon berikut "Intinya kita bikin yang mudah, aman, kalua bamboo bisa dibeli atau bahkan dibuat sendiri, anak-anak kan suka jajan juga, biasaya pakai bambu sebagai alatnya jadi anak lebih familiar. Selain itu, ini ramah lingkungan, kalua pakai sedotan 'kan dari plastik” (Dosen D, 14 September 2018). 
Lebih lanjut sesuai dari kesimpulan yang terjadi dalam tahap perencanaan, diputuskan beberapa kesepakatan. Pertama yaitu media yang digunakan dalam RPP dan yang kedua yaitu kesepakatan terkait pelaksaaan tahap do untuk melakukan observasi selanjutnya. Sebelum dari kolaborasi lesson study terjadi, guru hanya mengandalkan pembelajaran konvensional, sehingga dengan penggunaan media ini Ibu R dan observer lainnya tampak antusias untuk melaksanakannya.

Pada tahap $d o$, dilakukan kegiatna pembelajaran team teaching antara dosen $\mathrm{D}$ dan Ibu $\mathrm{R}$ selaku guru kelas pada tanggal 25 September 2019. Pada Gambar 1 tampak siswa sedang mengamati pembelajaran yang berlangsung. Beberapa hasil catatan lapangan dari observer yang bertugas tampak bahwa siswa terlihat antusias, meskipun beberapa sisiwa tampak terduduk lesu dikarenakan dampak dari kelelahan fisik setelah melaksanakan pembelajaran olahraga tepat pada jam pelajaran sebelumnya. Secara umum kesiapan fisik dalam pembelajaran juga menjadi hal yang patut diperhatikan guru (Mulyani, 2013; Tsabitah \& Wahyudin, 2016).

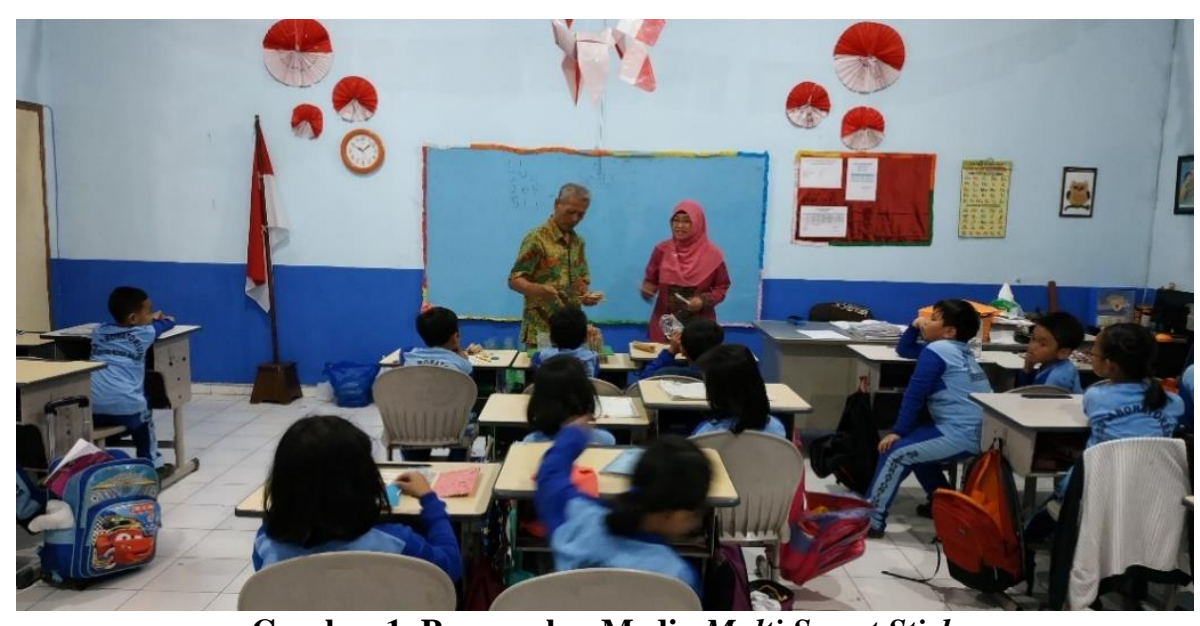

Gambar 1. Pengenalan Media Multi Smart Stick

Hasil catatan para observer menunjukkan siswa secara aktif terlibat dalam kelompok kecil saat penggunaan media dalam pengerjaan soal matematika muatan penjumlahan. Pada kegiatan selanjutnya yaitu terkait dengan proses melibatkan siswa dalam kegiatan menanya dan mencoba, siswa secara antusias maju untuk mengambil media untuk menyelesaikan permasalahan yang disajikan dosen model. Siswa secara berkelompok antusias mencoba untuk mendemonstrasikan media seperti yang dilakukan oleh dosen model. Dalam tahap ini, guru dan dosen model berkolaborasi untuk memberikan bimbingan kepada siswa di tiap-tiap kelompok. Adapun kegiatan selanjutnya yang dilakukan yaitu siswa memberikan demonstrasi di depan kelas dan kemudian seluruh kelas memperhatikan penjelasan dan penguatan dosen model.

Berdasarkan hasil lembar observasi lesson study pada tanggal 25 September 2019, diketahui bahwa hanya sebagian kecil siswa yang tidak antusias. Ibu H menyatakan bahwa "Ada satu siswa yang tampak kurang antusias dengan pembelajaran hari ini, siswa tampak lelah dan kurang 
bersemangat. Dimungkinkan penyebabnya adalah karena siswa tersebut mengikuti jam pelajaran olahraga. Solusinya ada jeda waktu sebelum memasuki jam pelajaran berikutnya." Hal tersebut juga dikuatkan oleh hasil observasi dari Ibu A yang menyatakan bahwa "Karena pembelajaran setelah pelajaran olah raga, siswa jadi kelelahan sehingga perlu jam istirahat." Secara keseluruhan dari hasil observasi para observer menunjukkan bahwa siswa antusias dalam melaksanakan pembelajaran. Catatan menunjukkan bahwa fakta di lapangan siswa terlihat aktif mendengarkan penjelasan dosen D dan Ibu R selaku dosen dan guru model terkait dengan media yang digunakan.

Tahapan selanjutnya yaitu tahap refleksi yang dilakukan setelah pembelajaran berlangsung menunjukkan bahwa adanya beberapa poin penting yang diperoleh. Pertama yaitu terkait penguasaan kelas. Hal ini dikarenakan siswa akan lebih antusias terhadap pembelajaran apabila guru memiliki penguasaan kelas yang maksimal (Aprilyani, 2015).. Hal tersebut ditunjukkan dengan fakta hasil observasi dari Ibu $\mathrm{H}$ dan A yang menyatakan bahwa penguasaan kelas menjadi peran penting dalam pembelajaran terutama di kelas rendah Sejalan dengan pernyataan tersebut, Ibu A juga menyantakan hal yang senada, yaitu "guru harus betul-betul menguasai pengelolaan kelas dan harus aktif'. Kedua yaitu terkait dengan media yang digunakan, terdapat saran untuk tindakan selanjutnya yaitu terkait dengan pelabelan tempat bilangan satuan, puluhan, dan ratusan. Hal ini mendorong tim terlibat untuk melakukan perbaikan RPP pada pelaksaan do berikutnya. Secara umum, upaya reflektif dalam tahap lesson study mendukung kegiatan penelitian tindakan kelas yang dilakukan (Lewis et al., 2009).

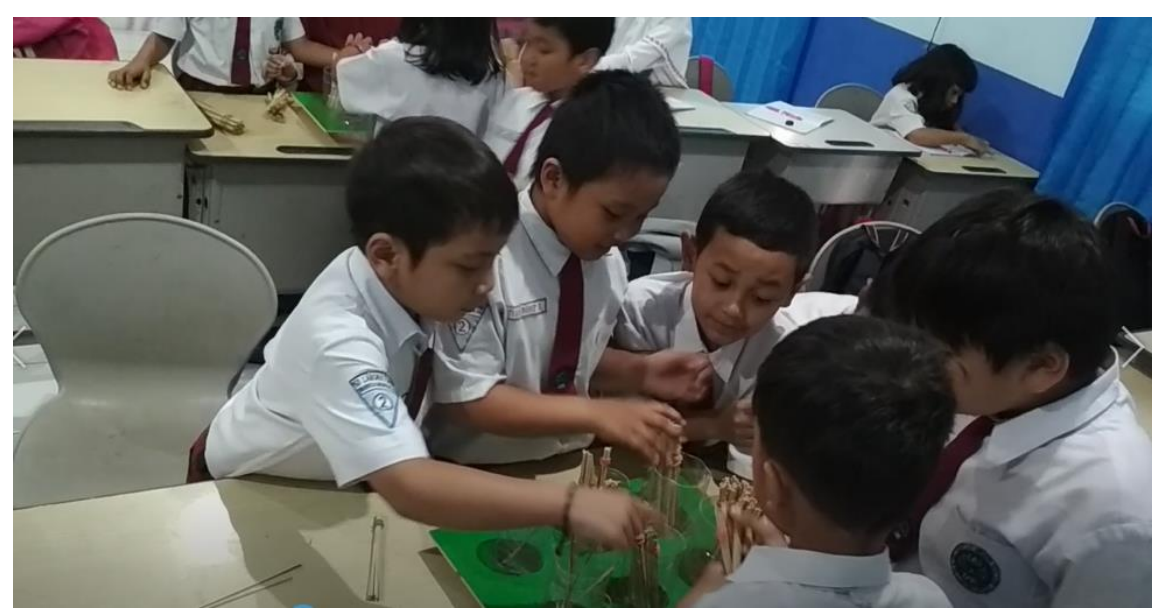

\section{Gambar 2. Siswa Bekerja dalam Kelompok dengan Menggunakan Media Multi Smart Stick}

Secara keseluruhan pemebelajaran menggunakan media Multi Smart Stick berjalan dengan baik, mulai dari kegiatan awal, kegiatan inti sampai kegiatan penutup, anak aktif dalam mengikuti kegiatan pembelajaran yang berlangsung. Jika ditinjau dari data penelitian tindakan kelas, yaitu data post test, pencapaian siswa berada pada angka 64,4 sehingga didapatkan peningkatan $2,8 \%$ dari skor 
pretest sebesar 61,6. Terlebih lagi, secara keseluruhan, siswa aktif menjawab dan berdiskusi dalam kelompok untuk mencoba dan mengkomunikasikan hasil pemecahan masalah dengan menggunakan Multi Smart Stick. Selain itu, dokumentasi menunjukkan siswa secara aktif terlibat dalam kelompok dengan lebih baik dibandingkan sebelumnya yang disajikan pada Gambar 2.

Dalam pelaksanaan observasi tampak siswa larut dalam pembelajaran menggunakan media, selain itu data diskusi antar siswa menunjukkan bahwa mereka mulai mengenal sistem penggunaan media tersebut dengan baik dan saling membenarkan temannya saat saat menghitung atau salah meletakkan media tersebut. Saat sesi pengerjaan soal di papan tulis, siswa tampak sangat antusias untuk mengerjakan bahkan beberapa kelompok tampak ingin maju dan tidak memilih wakilnya. Hal yang patut dicatat dalam kegiatan do kali ini adalah tampak bahwa media pembeljaran yang sudah familiar bagi siswa akan lebih membatu pelaksanaan pembelajaran dengan lebih mudah. Siswa menjadi lebih cepat dalam menangkap dan menyelesaikan tugas yang diberikan dengan penggunaan media yang tepat (Sutiarso \& Coesamin, 2018; Widodo, 2018).

Terkait dengan pelaksaan penyelesaian PTK, guru dan dosen tim berkolaborasi dalam penulisan draft penelitian tersebut. Pada tahap ini tampak bahwa data dari hasil lesson study membantu tim dalam memperkaya data secara kualitatif. Secara umum, hal ini mengimplikasikan bahwa lesson study tampak memberikan kontribusi lebih dalam pelaksanaan PTK yang sebelumnya hanya berfokus pada penyelesaian masalah. Data dukung didapatkan dalam tahap refleksi yang tampak bahwa banyak sekali inspirasi dan saling berbagi pengalaman yang dilakukan terlebih lagi Ibu $\mathrm{H}$ dan Ibu A yang merupakan guru kelas tinggi juga mempelajari cara yang berbeda untuk mendekatkan diri dengan siswa kelas rendah. Dosen D juga merasakan demikian, adanya perubahan cara mengajar dari andragogi menjadi pedagogi juga menjadi nilai lbeih bagi pengalaman beliau. Hal tersebut tampak pada statement wawanwcara berikut. "Ya, biasanya ngajar mahasiswa sekarang ngajar anak kelas 2, awalnya ngos-ngosan tapi sangat menantang" (Dosen D, 20 Oktober 2018)

Pengggalian nilai positif tampak bahwa dalam program PDS yang dilakukan melalui pembuatan PTK berbasis lesson study tampak bahwa kelompok guru dan dosen terlibat secara aktif dalam pengambangan diri. Hal ini menunjukan bahwa adanya kaitan antara kerja kolaboratif, dan hubungan positif di sekolah dapat terjadi dengan menggunakan lesson study di semua tahap yang membutuhkan kerja sama tinggi dari tim lesson study tersebut (Lewis et al., 2009; Murata, 2011; Puchner \& Taylor, 2006). Implikasi dari studi kasus ini menunjukkan bahwa adanya nilai positif dari pelakasanaan PTK yang berbasis lesson study. Melalui dukungan dari perguruan tinggi, yaitu mentoring dari dosen, guru secara aktif terlibat dalam peningkatan kualitas profesionalisme dirinya melalui pelaksanaan tindakan kelas. 


\section{SIMPULAN DAN SARAN}

\section{Simpulan}

Tujuan dari penelitian ini adalah untuk memotret pelaksanaan tindakan kelas sebagai upaya untuk peningkatan profesionalisme guru yang diimplementasikan melalui lesson study. Data hasil penelitian menunjukkan indikasi bahwa guru belum pernah melakukan kolaborasi sebelumnya. Berdasarkan hasil wawancara dinyatakan bahwa guru belum pernah melaksanakan PTK dengan kolaboratif lesson study. Terlebih lagi ada indikasi dari minat guru terhadap pengembangan diri yang lebih tinggi melalui pelaksanaan penelitian tindakan kelas. Pada pelaksanaanya, PTK berbasis lesson study terdiri dari tiga tahap yaitu plan, do, dan see. Dalam tahap plan terjadi penentuan keputusan materi, media, dan setting kelas yang digunakan untuk pelaksanaan PTK. Selama tahap $d o$, para observer antusias mencatat di lembar observasi dan menyajikan data untuk kegaitan refleksi seusai pembelajaran berlangsung. Pada tahap see, kegiatan yang dilakukan adalah proses refleksi pembelajaran sehingga didapatkan beberapa poin penting dari hasil pelaksanaan kegiatan.

Terkait dengan penyelesaian PTK, sebagai sebuah luaran akhir dalam pelaksanaan program kolaboratif, tampak bahwa data dari hasil lesson study membantu tim dalam memperkaya data secara kualitatif. Secara umum hal ini mengimplikasikan bahwa lesson study tampak memberikan kontribusi lebih dalam pelaksanaan PTK yang sebelumnya hanya focus pada penyelesaian masalah saja. Selain itu, dengan adanya lesson study dapat meningkatkan kemampuan guru dalam peningkatan kinerja diri dengan melaksanakan sebuah penelitian.

\section{Saran}

Berdasarkan simpulan hasil penelitian tersebut, tampak bahwa beberapa implikasi terkait dengan praktik pendidikan. Pertama yaitu penggunaan lesson study diharapkan dapat menjadi sebuah kegaitan rutin yang dilakukan di sekolah, selain untuk meningkatkan kualitas pembelajaran tetapi juga dapat meningkatkan kualitas diri guru dalam rangka profesionalitas guru. Saran bagi peneliti selanjutnya yaitu dibutuhkan temuan lainnya dalam segi metode yaitu pelaksanaan metode kuantitatif untuk mendukung data baik dari segi persepsi guru terhadap PTK ataupun lesson study sehingga data yang didapat menjadi lebih utuh. Lebih lanjut, penelitian selanjutnya diharapkan dapat lebih fokus terhadap segi kolaboratif antara perguruan tinggi selaku Lembaga Penyelenggara Tenaga Kependidikan (LPTK) dengan sekolah sebagai latar praktisi keguruan yang ada sebagai upaya pengurangan kesenjangan antara penggagas teori dan praktik di lapangan.

\section{DAFTAR RUJUKAN}

Anggara, R., \& Chotimah, U. (2012). Penerapan lesson study berbasis musyawarah guru mata pelajaran (MGMP) terhadap peningkatan kompetensi profesional guru PKN SMP se-kabupaten Ogan Ilir. Jurnal Forum Sosial, 5, 107-203. Jurusan Pendidikan Ilmu Pengetahuan Sosial Fakultas Keguruan dan Ilmu .... 
Aprilyani, F. (2015). Persepsi Guru Kelas Rendah Terhadap Pelaksanaan Pembelajaran Dalam Kurikulum 2013 di SD Negeri Se-Kelurahan Ngringo Kecamatan Jaten Karanganyar (PhD Thesis). Universitas Muhammadiyah Surakarta.

Arreman, I. E. (2005). Research as power and knowledge: Struggles over research in teacher education. Journal of Education for Teaching, 31(3), 215-235.

Beijaard, D., Meijer, P. C., \& Verloop, N. (2004). Reconsidering research on teachers' professional identity. Teaching and Teacher Education, 20(2), 107-128.

Blakemore, H. (2012). Emergent teacher-researchers: A reflection on the challenges faced when conducting research in the English classroom. English Teaching: Practice and Critique, 11(2), 59-69.

Brew, A., \& Boud, D. (1995). Teaching and research: Establishing the vital link with learning. Higher Education, 29(3), 261-273.

Cammarota, J., \& Fine, M. (2010). Youth participatory action research: A pedagogy for transformational resistance. In Revolutionizing education (pp. 9-20). Routledge.

Chou, C. (2011). Teachers' Professional Development: Investigating Teachers' Learning to Do Action Research in a Professional Learning Community. Asia-Pacific Education Researcher (De La Salle University Manila), 20(3).

Dewi, R. (2010). Profesionalisasi Guru Melalui Penelitian Tindakan Kelas. Pascasarjana Unimed.

Ellis, R. (1997). SLA Research and Language Teaching. ERIC.

Fitriani, K., \& Maulana, M. (2016). Meningkatkan Kemampuan Pemahaman dan Pemecahan Masalah Matematis Siswa SD Kelas V Melalui Pendekatan Matematika Realistik. Mimbar Sekolah Dasar, 3(1), 40-52.

Forgasz, H., \& Markovits, Z. (2018). Elementary Students' Views on the Gendering of Mathematics. European Journal of Educational Research, 7(4), 867-876.

Laurens, T., Batlolona, F. A., Batlolona, J. R., \& Leasa, M. (2018). How does realistic mathematics education (RME) improve students' mathematics cognitive achievement. Eurasia Journal of Mathematics, Science and Technology Education, 14(2), 569-578.

Lewis, C., Perry, R., \& Friedkin, S. (2009). Lesson study as action research. The SAGE Handbook of Educational Action Research, 142-154.

Markovits, Z., \& Forgasz, H. (2017). "Mathematics is like a lion": Elementary students' beliefs about mathematics. Educational Studies in Mathematics, 96(1), 49-64.

Mertler, C. A. (2009). Action research: Teachers as researchers in the classroom. Sage.

Mettetal, G. (2002). The what, why and how of classroom action research. Journal of the Scholarship of Teaching and Learning, 6-13.

Morrell, P. D., \& Carroll, J. B. (2010). Conducting educational research: A primer for teachers and administrators. Brill Sense.

Muhsetyo, G., Krisnadi, E., \& Wahyuningrum, E. (2014). Pembelajaran matematika SD.

Mulbar, U., \& Zaki, A. (2018). Design of Realistic Mathematics Education on Elementary School Students. Journal of Physics: Conference Series, 1028, 012155. IOP Publishing.

Mulyani, D. (2013). Hubungan kesiapan belajar siswa dengan prestasi belajar. Konselor, 2(1).

Murata, A. (2011). Introduction: Conceptual overview of lesson study. In Lesson study research and practice in mathematics education (pp. 1-12). Springer.

Phonguttha, R., Tayraukham, S., \& Nuangchalerm, P. (2009). Comparisons of mathematics achievement, attitude towards mathematics and analytical thinking between using the geometer's sketchpad program as media and conventional learning activities. Mathematics Learning, 7(19.083), 407.

Prihantoro, R. (2011). Pengembangan Profesionalisme Guru Melalui Model Lesson Study. Jurnal Pendidikan Dan Kebudayaan, 17(1), 100-108.

Puchner, L. D., \& Taylor, A. R. (2006). Lesson study, collaboration and teacher efficacy: Stories from two school-based math lesson study groups. Teaching and Teacher Education, 22(7), 922-934.

Rozak, A., \& Fauziah, E. (2013). Implementasi lesson study sebagai upaya peningkatan kompetensi pedagogik guru bahasa indonesia di SMP kabupaten Cirebon. Jurnal Pendidikan Bahasa Dan Sastra, 13(1), 1-11.

Schmuck, R. A. (2006). Practical action research for change. Corwin Press.

Sidabutar, R. (2016). The Efforts to Improve Mathematics Learning Achievement Results of High School Students as Required by Competency-Based Curriculum and Lesson Level-Based Curriculum. Journal of Education and Practice, 7(15), 10-15.

Sirojjuddin, S., Triyoso, A., \& Jusmin, J. (2019). Implementasi Program Penugasan Dosen di Sekolah. Jurnal Abdimasa, 2(1), 6-9. 
Somekh, B., \& Zeichner, K. (2009). Action research for educational reform: Remodelling action research theories and practices in local contexts. Educational Action Research, 17(1), 5-21.

Subadi, T. (2012). Pengembangan Model Peningkatan Kualitas Guru Melalui Pelatihan Lesson Study Bagi Guru SD Karesidenan Surakarta.

Susilo, H. (2013). Lesson Study sebagai sarana meningkatkan kompetensi Pendidik. Makalah) Disajikan Dalam Seminar Dan Lokakarya PLEASE, 28-34.

Susilo, H., Husnul, C., Ridwan, J., \& Jumiati, Y. (2009). Lesson study berbasis sekolah: Guru konservatif menuju guru inovatif. Malang: Bayumedia.

Sutiarso, S., \& Coesamin, M. (2018). The Effect of Various Media Scaffolding on Increasing Understanding of Students' Geometry Concepts. Journal on Mathematics Education, 9(1), 95-102.

Tsabitah, D., \& Wahyudin, A. (2016). Peran Kesiapan Belajar dalam Memediasi Pengaruh Kesiapan Belajar dan Fasilitas Belajar Terhadap Hasil Belajar Akuntansi. Economic Education Analysis Journal, $5(1)$.

Widodo, S. A. (2018). Selection of Learning Media Mathematics for Junior School Students. Turkish Online Journal of Educational Technology-TOJET, 17(1), 154-160.

Winarsih, A., \& Mulyani, S. (2012). Peningkatan profesionalisme guru IPA melalui lesson study dalam pengembangan model pembelajaran PBI. Jurnal Pendidikan IPA Indonesia, 1(1).

Yeni, E. M. (2011). Pemanfaatan benda-benda manipulatif untuk meningkatkan pemahaman konsep geometri dan kemampuan tilikan ruang siswa kelas V sekolah dasar. Jurnal Edisi Khusus, 1, 63-75. 